\title{
First confirmed record of Pomatoschistus microps (Krøyer, 1838) (Pisces: Gobiidae) from the Ionian Sea with notes on habitat and distribution
}

\author{
Francesco TIRALONGO ${ }^{1,2^{*}}$, Ioannis GIOVOS ${ }^{3}$, Giuseppina MESSINA ${ }^{1,2}$, \\ Daniele TIBULLO ${ }^{1,4}$ and Bianca Maria LOMBARDO ${ }^{2}$ \\ ${ }^{1}$ Ente Fauna Marina Mediterranea, Avola, Italy \\ ${ }^{2}$ Department of Biological, Geological and Environmental Sciences, \\ University of Catania, Catania, Italy \\ ${ }^{3}$ iSea, Environmental Organization for the Preservation of the Aquatic Ecosystems, \\ Thessaloniki, Greece \\ ${ }^{4}$ Department of Biomedical and Biotechnological Sciences, University of Catania, Italy \\ "Corresponding author: francesco.tiralongo@unict.it
}

\begin{abstract}
Two specimens of the common goby (Pomatoschistus microps) were observed in the estuarine environment of the River Asinaro (Sicily). These records represent the easternmost and southernmost observations of the species in the Mediterranean Sea, and the first confirmed record in the Ionian Sea (central Mediterranean Sea). We also provide notes about its habitat and current distribution in the Mediterranean Sea.
\end{abstract}

Key words: gobies, Mediterranean Sea, estuarine environment, brackish waters, river.

\section{INTRODUCTION}

Gobiidae is one of the largest families of fish, comprising more than 1800 species distributed in more than 250 genera (FROESE \& PAULY, 2019). Most species are of Indo-West Pacific origin, but are also widely distributed in temperate waters of both northern and southern hemispheres (NELSON et al., 2016).

In a natural environment, the identification of the species of the genus Pomatoschistus Gill, 1863 is not always possible, and several species require accurate morphological, meristic and color pattern analysis in order to be identified (KNeBelsberger \& THIEL, 2014). Pomatoschistus microps (Krøyer, 1838), commonly known as the "common goby", is a small marine and brackish species of goby (Gobiidae), considered rare in the Mediterranean Sea, where its distribution is limited to the northwestern part (AHNELT, 1991; LOUISY, 2006: PATZNER, 2016): Spain, France and Italy. Its distribution extends to the eastern Atlantic, from Norway to Morocco, including the Baltic Sea (FROESE \& PAULY, 2019). In Italy, although the species was reported in the grey literature (COSTA, 1991) for the area of the Strait of Messina (Lake Faro) and in the coastal lagoon of Venice (northern Adriatic Sea), LOUISY (2006), RELINI \& LANTERI (2010) and PATZNER (2016) did not consider these records. The only Italian recognized record of the species comes from the Ligurian Sea (LOUISY, 2006; RELINI \& LANTERI, 2010; PATZNER, 2016). 
The maximum reported total length (TL) of this species is $90 \mathrm{~mm}$, and common sizes range between 30 and $70 \mathrm{~mm}$ of TL. The body is slender, scales in lateral series are between 39 and 52, $\mathrm{D}_{1}$ : VI (V-VII), $\mathrm{D}_{2}$ : I + 8-9, A: I + 8-9, P: 17-19. The background body color is brownish or greyish, with blackish spots along the midline. A black stripe on the snout and cheeks are covered with small dark spots. The common goby exhibits an early maturation and a short lifespan. Spawning is multiple and mature males guard the nest (BOUCHEREAU \& GUELORGET, 1998). It occurs in brackish waters (lagoons and estuaries) and shallow marine waters (BOUCHEREAU, 1997), where the salinity is low (BOUCHEREAU et al., 1993; PAMPOULIE et al., 2000).

\section{MATERIAL AND METHODS}

On $18^{\text {th }}$ September 2018, two specimens of the common goby, $P$. microps, were sampled with a hand net in the estuarine environment of the River Asinaro $\left(36.87582^{\circ} \mathrm{N}, 15.13670^{\circ} \mathrm{E}\right)$, in Sicily (Ionian Sea) (Fig. 1), at about 40 meters from the sea and at a depth between $0.2-0.5 \mathrm{~m}$. Specimens were analyzed, identified following PATZNER (2016) and subsequently preserved in alcohol $80 \%$ and deposited in the Zoological Collection of Ente Fauna Marina Mediterranea with the code \#EFMM180918.

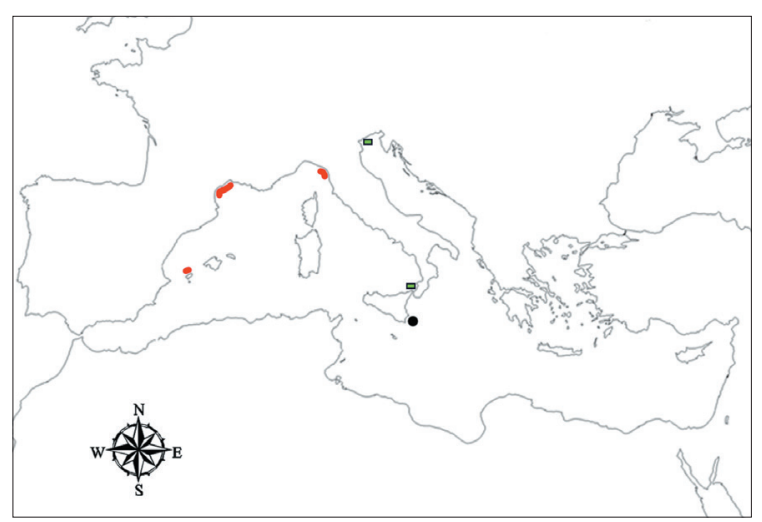

Fig. 1. In red: Mediterranean records of Pomatoschistus microps; green rectangle: records from grey literature (COSTA, 1991); black circle: new record (Ionian Sea)

\section{RESULTS AND DISCUSSION}

Morphological, meristic and color pattern analysis allowed us to identify the species as $P$. microps. The two specimens measured 32 and $35 \mathrm{~mm}$ (Fig. 2) in total length (TL). The bottom of the river was sandy and covered by green algae and dead leaves of Posidonia oceanica. Amphipods of the family Corophiidae, known to be one of the main preys of this species (MILLER, 1986), were found among the bottom vegetation. The species was quite elusive and difficult to catch with hand net. In the same and following days, several specimens $(>10)$ were observed in the same location (estuary of the River Asinaro).

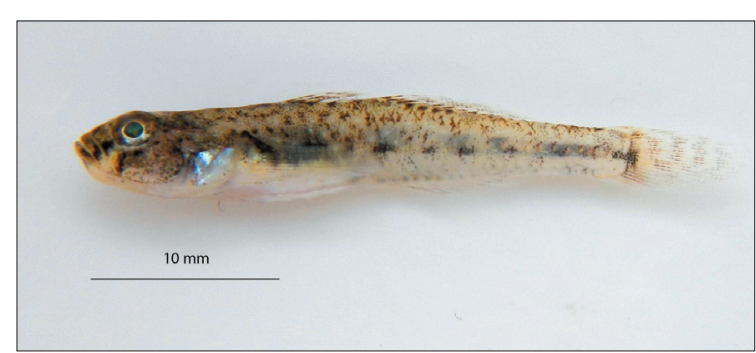

Fig. 2. A specimen of Pomatoschistus microps sampled in the River Asinaro (Ionian Sea)

Due to their cryptic nature, cryptobenthic fishes are difficult to detect and sample without adequate methods and targeted studies (PATZNER, 1999; BELDADE \& GONÇAVLES, 2007; KOVAČIĆ et al., 2012; TIRALONGO \& BALDACCONI, 2015; TIRALONGO et al., 2016a; TIRALONGO et al., 2016b). In this regard, the presence and abundance of several small Mediterranean gobies are in all likelihood underestimated (COLOMBO \& LANGENECK, 2013; TIRALONGO \& PAGANO, 2015; BILECENOGLU \& YOKES, 2016; KAMPOURIS et al., 2019).

P. microps is a small goby whose distribution in the Mediterranean Sea appears to be fragmented, similarly as in the case of Pomatoschistus bathi Miller, 1982 (GIACOBBE et al., 2018). Although several environmental factors, such as water temperature and salinity, play an important role in species distribution, the few records of $P$. microps from the Mediterranean Sea could be, at least in part, due to lack of targeted studies. Indeed, due to its small size, difficult identification, restricted habitat and lack of 
commercial interest, the presence of $P$. microps along the Mediterranean coasts could have been underestimated.

This record represents the easternmost and southernmost confirmed observations of the species in the basin, and the first confirmed record for the Ionian Sea (central Mediterranean Sea). New field studies are necessary to further investigate the presence and abundance of this rare species in the Mediterranean Sea, which is probably more common and widespread than current records indicate.

\section{REFERENCES}

AHNELT, H. 1991. Some rare fishes from the western Mediterranean Sea. Ann. Nat. Mus. Wien., 92: 49-58.

BELDADE, R. \& E.J. GONÇALVES. 2007. An interference visual census technique applied to cryptobenthic fish assemblages. Vie Milieu, 57: 61-65.

BİLECENOGLU, M. \& M.B. YOKES. 2016. SCUBA observations reveal a wider distribution range for Thorogobius macrolepis (Teleostei: Gobiidae). Annales, Ser. Hist. Nat., 26(2): 197-202.

BOUCHEREAU, J.L. 1997. Biodiversity of tactics used by three Gobiidae (Pisces; Teleostei): Pomatoschistus minutus (Pallas, 1770), P. microps (Krøyer, 1838), Gobius niger Linnaeus, 1758 , to survive in a Mediterranean lagoon environment. Oceanol. Stud., 26(23): 153-170.

BOUCHEREAU, J.L. \& O. GUELORGET. 1998. Comparison of three Gobiidae (Teleostei) life history strategies over their geographical range. Oceanol. Acta, 23: 503-517.

BOUCHEREAU, J.L., J.P. QUIGNARD, J.C. JOYEUX \& J.A. TOMASINI. 1993. Structure du stock des géniteurs de la population de Pomatoschistus microps (Krøyer, 1838) (Gobiidae), dans la lagune de Mauguio, France. Cybium, 17: $3-15$.

COLOMBO, M. \& J. LANGENECK 2013. The importance of underwater photography in detecting cryptobenthic species: new in situ records of some gobies (Teleostei: Gobiidae) from Italian Seas with ecological notes. Acta Adriat., 54(1): 101-110.

COSTA, F. 1991. Atlante dei Pesci dei Mari Italiani. Mursia, Milano, 567 pp.

FROESE, R. \& D. PAULY. 2019. FishBase. World
Wide Web electronic publication. www.fishbase.org (accessed 02/2019).

GIACOBBE, S., A. SPINELLI, S. DE MATTEO \& M. KOVAČíc. 2018. First record of the Bath's goby, Pomatoschistus bathi (Miller, 1982), from central-south Italy: a southern proof of fragmented distribution restricted to the north? Mar. Biodiv., 48(2): 2243-2248.

KAMPOURIS, T.E., F. TIRALONGO \& I.E. BATJAKAS. 2019. First record of Didogobius schlieweni Miller, 1993 (Perciformes, Gobiidae) in Eastern Mediterranean Sea. Aqua, 25(1): 13-16.

KNEBELSBERGER, T. \& R. THIEL. 2014. Identification of gobies (Teleostei: Perciformes: Gobiidae) from the North and Baltic Seas combining morphological analysis and DNA barcoding. Zool. J. Linnean Soc., 172(4): 831-845.

KOVAČIĆ, M., R.A. PATZNER \& U.K. SCHLIEWEN. 2012. A first quantitative assessment of the ecology of cryptobenthic fishes in the Mediterranean Sea. Mar. Biol., 159: 2731-2742.

LOUISY, P. 2006. Guida all'identificazione dei pesci marini d'Europa e del Mediterraneo. Il Castello, Milano, $430 \mathrm{pp}$.

MILLER, P.J. 1986. Gobiidae. In: Fishes of the North-eastern Atlantic and the Mediterranean. Vol. III (Editors: Whitehead, P.J.P et al.), UNESCO, Paris, pp. 1019-1085.

NELSON, J.S., T.C. GRANDE \& M.V.H. WILSON. 2016. Fishes of the World. John Wiley and Sons, Inc., Hoboken, NJ, USA, 752 pp.

PAMPOUlie, C., J.L. BOUCHEREAU, E. ROSECCHI, G. POIZAT \& A.J. CRIVELLI. 2000. Annual variations in the reproductive traits of Pomatoschistus microps in a Mediterranean lagoon undergoing environmental changes: evidence of phenotypic plasticity. J. Fish Biol., 57: 1441-1452. 
PATZNER, R.A. 1999. Habitat utilization and depth distribution of small cryptobenthic fishes (Blenniidae, Gobiesocidae, Gobiidae, Tripterygiidae) in Ibiza (Western Mediterranean Sea). Environ. Biol. Fishes, 55(3): 207-214. PATZNER, R.A. 2016. Pomatoschistus microps (Krøyer, 1838). http://www.patzner.sbg. ac.at/Gobiidae/Pom_mic.htm

RELINI, G. \& L. LANTERI. 2010. Osteichthyes. Biol. Mar. Medit., 17: 649-674.

TIRALONGO, F. \& BALDACCONI R. 2015. First record of the combtooth blenny Microlipophrys adriaticus (Steindachner \& Kolombatovic, 1883) (Pisces, Blenniidae) for the Italian Ionian Sea. Check List, 11(3): 1646. TIRALONGO, F. \& A. PAGANO. 2015. On the presence of Gobius kolombatovici in the Ionian
Sea. In Crocetta et al., 2015. New Mediterranean Biodiversity Records. Mediter. Mar. Sci., 16(3): 682-702.

TIRALONGO F., D. TIBULLO, M.V. BRUNDO, F. PALADINI DE MENDOZA, C. MELCHIORRI \& M. MARCELLI. 2016a. Habitat preference of combtooth blennies (Actinopterygii: Perciformes: Blenniidae) in very shallow waters of the Ionian Sea, south-eastern Sicily, Italy. Acta Ichthyol. Piscat., 46(2): 65-75.

TIRALONGO F., D. TIBULLO, G. VILLANI, E. MANCINI, R. BALDACCONI, M.V. BRUNDO \& M. MARCELLI. 2016b. Hypleurochilus bananensis (Poll, 1959) (Pisces, Blenniidae) in Italian seas: distribution, habitat preference and sexual dimorphism. Acta Adriat., 57(1): 125-134.

Received: 13 February 2019

Accepted: 7 November 2019 


\title{
Prvi potvrđeni zapis o vrsti Pomatoschistus microps (Krøyer, 1838) (Pisus: Gobiidae) iz Jonskog mora s bilješkama o staništu i rasprostranjenosti
}

\author{
Francesco TIRALONGO *, Ioannis GIOVOS, Giuseppina MESSINA, \\ Daniele TIBULLO i Bianca Maria LOMBARDO \\ *Kontakt e-pošta: francesco.tiralongo@unict.it
}

\begin{abstract}
SAŽETAK
Dvije jedinke vrste Pomatoschistus microps zabilježene su u okolišu ušća rijeke Asinaro (Sicilija). Ovaj nalaz predstavlja najistočniji i najjužniji nalaz vrste u Sredozemnom moru i prvi potvrđeni nalaz u Jonskom moru. Također se navodi njegovo stanište kao i trenutna rasprostranjenost u Sredozemnom moru.
\end{abstract}

Ključne riječi: glavoči, Sredozemno more, estuarij, boćata voda, rijeka 
